\title{
ПРОБЛЕМЫ ОБУЧЕНИЯ ДЕТЕЙ \\ С РАССТРОЙСТВОМ АУТИСТИЧЕСКОГО СПЕКТРА В УСЛОВИЯХ ИНКЛЮЗИВНОЙ ШКОЛЫ
}

\author{
Бурлакова М.А., Федорова Н.Н.
}

ГБОУ СОШ № 81 Калининского района Санкт-Петербурга,

г. Санкт-Петербург, Российская Федерация

В статье рассматриваются проблемь обучения детей с РАС в инклюзивной школе и пути их решения.

Ключевые слова: аутизм; инклюзия; индивидуальные образовательные траектории; дезадаптация; социализащия.

\section{PROBLEMS OF TEACHING CHILDREN WITH AUTISM SPECTRUM DISORDER IN AN INCLUSIVE SCHOOL}

\author{
Burlakova M.A., Fedorova N.N. \\ Secondary school №81, Kalininsky district, \\ Saint-Petersburg, Russian Federation
}

The article deals with the problems of teaching children with ASD in an inclusive school and ways to solve them.

Keywords: autism; inclusion; individual educational trajectories; disadaptation; socialization.

Причины аутизма до сих пор неясны, вместе с тем, ключевым фактором в настоящее время признаются генетические нарушения. Клиническая картина раннего детского аутизма крайне неоднородна. Диапазон речевых нарушений также очень широкий. Все это говорит о том, что аутизм, по всей видимости, представляет собой не один, а множество разных синдромов, отличающихся друг от друга 
патогенезом, клинической картиной, и требующих различных подходов в обучении и коррекции. Поэтому одной из задач, которую мы поставили перед собой, является формирование диагностического портфеля и разработка комплексной диагностической карты, построенной с учетом современных представлений о проявлениях РАС. Результаты такого диагностического исследования позволяют определить направление коррекционного вмешательства, основанного на анализе всех имеющихся симптомов.

Ключевая проблема у детей с РАС - это нарушения и затруднения во взаимодействии и коммуникации с другими людьми. Если коммуникация выстраивается, то начинают формироваться механизмы адаптации в социуме, следом за которой появляется условия для социализации. Затруднения в коммуникации не означает, что ребенок не имеет мощную потребность в отношениях, в привязанности, в чувстве общности с другими людьми. Просто его затруднения являются барьером для реализации базовой потребности в отношениях

После школы ребенку с аутизмом предстоит жить в том же обществе, что и выпускникам обычных школ. Чем раньше они познакомятся друг с другом, тем выше шансы на то, что между ними сложится понимание и взаимодействие. Ребенку с аутизмом, который ходит в школу вместе с обычными детьми, гораздо проще будет ощущать себя частью общества, чем выпускнику коррекционной школы. Способность к коммуникации можно реализовать только в ситуации группы людей. Поэтому мы выбрали для проекта инклюзивную форму работы.

Анализ современного состояния сопровождения и обучения детей с РАС в инклюзивной школе выявил следующие проблемы:

- недостаточный уровень развития системы диагностики детей c РAC;

- отсутствие рекомендаций по проектированию специальной индивидуализированной образовательной среды с учетом специфики проявления симптоматики РАС у обучающихся на основе технологии эффективных коммуникаций; 
- низкий уровень информированности педагогических работников и родителей о проявлениях РАС, особенностях обучения и воспитания такой категории детей;

- недостаточное количество специалистов (педагоги-психологи, учителя-логопеды, учителя-дефектологи, педагоги), имеющих специальную подготовку и образование по вопросам оказания помощи детям с РАС;

- отсутствие системы психолого-педагогического сопровождения семей детей с $\mathrm{PAC}$;

- отсутствие в большинстве образовательных организаций условий для организации образовательного процесса, учитывающих специфику детей с РАC;

- отсутствие преемственности этапов образования и развития детей с РАС (начиная с раннего возраста).

Наиболее распространенными психолого-педагогическими методами стали прикладной поведенческий анализ (applied behavioral analysis, ABA), часто называемый «оперантной терапией», и ТЕACCH (treatment and education of autistic children and children with relative communicative handicap). В рамках ТЕАССН коррекционная работа направлена как на формирование различных навыков, так и на структурирование окружающей среды и времени. В коррекционной работе внутренние особенности психики детей с аутизмом в некоторой степени учитываются, однако основная, решающая роль в формировании социально приемлемого поведения отводится внешним факторам - организованным в мотивирующую систему различным видам стимулов (запускающих, помогающих вызвать требуемую реакцию, подкрепляющих). Анализ существующей практики показывает, что для разных категорий детей с ОВ3 должны быть разработаны и внедрены различные модели обучения, позволяющие максимально реализовать потенциал детей с РАС. В рамках реализации проекта в инклюзивной школе будет создана единая система, позволяющая разработать и реализовать индивидуальную образовательную траекторию ребенка с РАС и подготовить его к следующим жизненным этапам (профессиональному и предпрофессионально- 
му). Учителя, работающие в системе инклюзивного образования с обучающимися с РАС, будут получать дополнительные знания не только на краткосрочных курсах повышения квалификации, но и в системе внутрифирменного повышения квалификации при участии специалистов организаций-партнёров в сочетании с формированием практического опыта работы с детьми с РАС. Педагоги будут иметь возможность проконсультироваться со специалистами по текущим проблемам, возникающим в процессе работы. Будет проводиться регулярная супервизия со стороны специалистов, в т.ч. с использованием подготовленного портфеля диагностических материалов. Реализация проекта предусматривает организацию эффективного взаимодействия между участниками образовательных отношений на основе внедрения современных средств коммуникации, а также реализацию специальной программы обучения для родителей, обучающихся с РАС. Успешное включение в образовательную среду детей с РАС и выраженными проблемами поведения позволяет максимально реализовать потенциальные возможности их развития, повысить качество жизни и решить проблему изоляции не только самого ребенка, но и членов его семьи.

\section{Список литературы}

1. Башина В.М. К проблеме раннего детского аутизма. В сб.: Шизофрения и расстройства шизофренического спектра / Под ред. А.Б. Смулевича. М., 1999. С. 98-108.

2. Манелис Н.Г. Ранний аутизм. Психологические и нейропсихологические механизмы / Н.Г. Манелис. // Шк. здоровья. 1999. N 2. С. 6-22.

3. Пути помощи / Никольская О.С., Баенская Е.Р., Либлинг М.М. М.: Теревинф, 1997.

4. Алехина С.В. Инклюзивное образование для детей с ограниченными возможностями здоровья // Современные образовательные технологии в работе с детьми, имеющими ограниченные возможности здоровья: монография / Н.В. Новикова, Л.А. Казакова, С.В. Алехина; под общ. ред. Н.В. Лалетина; Сиб. Федер. ун-т, Краснояр. гос. пед. ун-т им. В.П. Астафьева [и др.]. Красноярск, 2013. С. 71-95. 


\section{References}

1. Bashina V.M. K probleme rannego detskogo autizma. V sb.: Shizofreniya i rasstroystva shizofrenicheskogo spektra / Pod red. A. B. Smulevicha. M., 1999. S. 98-108.

2. Manelis N.G. Ranniy autizm. Psikhologicheskie i neyropsikhologicheskie mekhanizmy/ N.G. Manelis // Shk. zdorov'ya. 1999. N 2. C. 6-22.

3. Puti pomoshchi / Nikol'skaya O.S., Baenskaya E.R., Libling M.M. M.: Terevinf, 1997.

4. Alekhina S.V. Inklyuzivnoe obrazovanie dlya detey s ogranichennymi vozmozhnostyami zdorov'ya // Sovremennye obrazovatel'nye tekhnologii v rabote s det'mi, imeyushchimi ogranichennye vozmozhnosti zdorov'ya: monografiya / N.V. Novikova, L.A. Kazakova, S.V. Alekhina; pod obshch. red. N.V. Laletina; Sib. Feder. un-t, Krasnoyar. gos. ped. un-t im. V.P. Astaf'eva [i dr.]. Krasnoyarsk, 2013. S. 71-95. 